\title{
Zebo Mirzo's poetry and image
}

\author{
Nigora Salohiddinova ${ }^{1}$ \\ ${ }^{1}$ Researcher of Andijan State University, University St. 129, Andijan city, Uzbekistan
}

Email: salohiddinova_n@umail.uz

\begin{abstract}
This article highlights the psychological experience of his poetic poems. Brief information on the life and work of Shoira Zebo Mirzo.

Keywords: lyric poetry, spiritual emotions, poetic perception, image, imagery, style.

\section{INTRODUCTION}

While watching the works of today's Uzbek poetry, we can see that the lyric poetry is becoming a priority. The creator is now rediscovering himself. A new look at the poetic perception of the universe, the tradition of new thinking is intensifying. Instead of the social spirit, singing the soul and the evolution of the heart is the main subject. This is especially evolving through independence.

In the poetry of independence, the desire to explore the emotional layers, the poetic discovery of rich, remote and colorful climates in the human mind. Particular attention was paid to putting the heart in control and removing the border. Zebo Mirzadyr, one of the most famous singers in the poems, does not know such boundaries.

Zebo Mirzo was born on December 15, 1964 in Beshterak village of Kitab district of Kashkadarya region. She studied at the Uzbek State University (1982-1987) at the Tashkent State University (present-day UzUU). Senior Lecturer, Teacher of the Tashkent State Institute of Arts (1987-1991), Editor-in-Chief of the Republican Center of Folk Art and Cultural Studies of the Ministry of Culture of the Republic of Uzbekistan (1991-1995), Publishing House "Yazor" (1995-1999), Senior Editor of Radio "Yoshlar" of National Television and Radio Company of Uzbekistan (1999-2006). From 2006 he worked as the editorin-chief of the Uzbekistan TV channel.
\end{abstract}

\section{THEORITICAL BACKGROUND}

The first poetry collection by Zebo Mirzo "Queen of the Night" was published in 1990. His poetic books such as "Ajr" (1997), "Light Powder" (2004), "Ishq" (2012) were born. Zebo Mirzo also speaks about the cultural-historical and cultural heritage of fine art, culture and literature, such as "The World of Color", "The School of Educa", "The Life of the Art", " He is also the author of a series of series of educational programs on educational issues.

The poet and critic of Hurshid Davron, the author of the book "Love" by Zebo Mirzo, is worth mentioning. "The role of poets in today's Uzbek poetry, and, to say more frankly, has an equal status with men's poetry. This is one of the poets whom Zhan was appointed and appointed. " Indeed, as we observe the poet's work, we can witness the strongest pitilesses, sorrows, and psychological conflicts in the universe. Khurshid Davron continues, "As I saw the heart of Zebo in my hand, I felt as if I were in the heart of the heart. The poet can inspire himself in many poems, and he opens the world to the most vulnerable layers of his heart, as if he were insane. In these poems, "the light and the shadow are added", "the great heart, which conceals the grass of the grass, and which has not been able to draw a small leaf."

Indeed, as we read poetry poems, we experience the mysterious colors of love. We feel as though we are thinking. The reader is pleased to hear that the heart is so awkward, and the sincerity and sincerity of the emotions he has been wearing. The calmness and the tenderness in poetry, and the violentness of the poetry, make the reader delight. 


\section{MAIN PART}

Zebo Mirzo is a unique poem which can bring the original style of the Uzbek poetry into a new style and style. In his poetry, not only the delicate experiences of a woman's heart, but also poetic discoveries that are common to the world's worries. His emotions are true, he can speak the world through artistic characters,

As noted by prominent critic O. Sharafiddinov, "The poet also makes great discoveries - creating a world full of unique colors, charming sensations, magic meanings and dignified wisdom."

Thus Zebo Mirzo liras is a series of unique images. The poet has a new look at the motifs of all forms of mountains such as mountains, trees, trees, moon, stars, clouds, cocaine, grass, garden, flower, bird, butterfly, sea, forest, night, sun, passes the nouns, expresses his thoughts, and brings unexpected conclusions. He follows his thoughts and influences his emotional and intellectual power and makes him the partner of his poetry. So, one can say that the new image of the poet is a new one!

\section{Kim jilovlay oladi uni? \\ Bormi bir qo'l, \\ Bormi bir odam- \\ Kelganida jasorat kuni \\ Bo'ronlarni uyg'otadigan? \\ Tun-bu g'aflat, \\ Tun mo'jizakor, \\ Sirlarini ochganda to'lib, \\ Ko'kka qanot yozadi tulpor. ${ }^{1}$}

The poet propagates the idea of greatness and evil in this poem. It's the only one to explore the horse image in black. We know that the horse is the embodiment of beauty and beauty. If the goodness that comes to human consciousness is considered to be a sign of goodness, then it turns into greatness. On the contrary, it leads to mischief. From this point of view, the artist wants to know who can control these perceptions and who is able to fight evil. Keeping in mind that it is in the hands of anyone that it is possible to spend the opportunity alone with evil, or to build the miraculous way of life.

\section{Bu yer ummon bo'lgan bir vaqtlar...$$
\text { Keyin ko'tarilgan }
$$$$
\text { ulkan toshlari, }
$$$$
\text { Keyin suv qurigan }
$$$$
\text { va cho'kkan... }
$$$$
\text { Tog'lar- }
$$ \\ Yerning qotib qolgan metin yoshlari \\ Endi koinotning \\ ko'm-ko'k dengizi \\ Sirli jilvasiga bo'lganicha g'arq \\ Shundoq yulduzlarning ko'zi o'ngida \\ Ochilib yotibdi \\ milyon yillik Vaqt!... ${ }^{2}$}

What does the creator mean? What is its purpose? Is it the scene of human psychology or nature? Everyone in the heart of the seeds of kindness first of all sows. But the various challenges of life can ruin a person's will. Truthfulness, slander, indulgences - let's say all the negative things are breaking the heart. That is the will of man. He can distinguish between right and wrong from truth. But now he is completely different. A kind person is transformed into a brilliant human being rather than a bumehr. It is quite successful to draw poet-psychological phenomena in the poems of Zebo Mirzo, without specifying one or another phenomenon, to stimulate the reader's thinking about it.

It is difficult for a poet to read his poems in one reading. Because his thoughts are a little new, and it causes some confusion. To do this, the reader needs the breadth and depth of the imaginary world.

\footnotetext{
${ }^{1}$ M.Zebo. Ishq.- Tashkent.- “Akademnashr”.- 2011 .- C.89.

${ }^{2}$ M.Zebo. Ishq.- Tashkent.- “Akademnashr”.-2011 .- C.84.
} 
Only then the mysterious world of the artist's heart becomes clear to the reader. It does not leave any readers indifferent. That is the peculiarity of Zebo Mirzo's creativity.

Zebo Mirzo is as impressive as most pencils. And, of course, this feature is reflected in his poetry. The poet uses the phrase "O", "Oh", which gives an emotionally-expressed expression in many places:

\section{O, esimda, ma'yus gul kabi \\ Yodingizda to'kilishlarim. \\ To tonggacha qilib ibodat, Sevgingizga yukinishlarim... \\ $O$, qandayin munis dard edi \\ Yuvvosh, o'ychan ayolning holi \\ Kundan kunga olovlanardi \\ Jismi, ruhi, umri, hayoli...}

"What gives rise to the inadequacy of the word magic is the perfection of the poetic context." That is, with the creative thinking, the word becomes new to the new temptation. Such transformations, in turn, appear in symbolic images and symbols.

It is not without exaggeration to say that the expression of the world through symbolic images and symbols is at the highest point in the poetry of Zebo Mirzo. The poet himself says, "It is worldshaped, if you can see it. Clouds in the sky, traces on the tree, mudflows from the wall, marble stripes on the underground ... You can get to know the amazing scenes from all sides, if your imagination endures ... "He finds you anywhere, anywhere" , - writes in the end of the book "Love".

Every creator must carefully observe the sophistication of the language that he uses to make the mentality more accurate. It is impossible to express himself, to express his feelings in words. Zebo Mirzo is one such creator. His creativity is a unique phenomenon in contemporary Uzbek poetry. In the poem poems, the word is full of its power, vigor and charm. It also enlivens the word, not only the feelings but also the sight.

\section{Ko'ngil g'orat bo'lgan zaminga o'xshar, Qanday chidash mumkin bu qabohatga? Yuragimni qora ilonlar chaqar,} Chayon malham qo'yar ko'r jarohatga...

Being a misfortune means being overconfident; The heroic hero is losing his heart. This is a black snake, when the enemies bribe its heart, and the scorpions are in trouble. In fact, snakes and scorpions are the same people in our group. Only evil can do them. As you read the poem carefully, the scorpion image appears as a hypocrite. In this poem called "My Dream," we can see that people around us are not always friends, and that there are many different people among them. The last poem is a special mood:

\section{Ulardan qo'rqmayman, billanihoya, \\ Har on ko'zimga mil tortsa-da sabrim. \\ Senga boqib turgan yuzimni \\ Bir dam}

Sendan o'girishdan qo'rqaman, Rabbim! ${ }^{3}$

Yes, indeed, man will be prevented from many evil. Anger is an enemy of man.

\section{CONCLUSION}

The creator simply tells them that they are not afraid of them, because they are at the end. He does not want his soul to be concealed and to turn his face towards Allah. This poem, of course, gives a person spiritual training.

It is absolutely thrilling to see such lyricism in a pure form and to reach the heart of the reader. As the late poet Erkin Vohidov said: "Poetry is a language dialogue between the poet and the reader. For the poet this conversation is to open the heart to understand the heartbeat of the reader".

\footnotetext{
${ }^{3}$ M.Zebo. Ishq.- Tashkent.- “Akademnashr”.- 2011 .- C.46-47.
} 


\section{REFERENCES}

1. M.Zebo. Ishq.- Tashkent, “Akademnashr” 2011.- P. -128.

2. Sharafiddinov. O. Ijodni anglash baxti. - Tashkent,- Sharq. -2004.-P. 640.

3. Vohidov.E Yozuvchi va davr. - Tashkent . Yosh gvardiya. -1987.-P. 224.

4. Sharopov.A. Yulduzli osmon siri. - T. G'afur G'ulom nomidagi adabiyot va san'at nashriyoti. 1983.-P. 168. 